\title{
Learning in a Credit Crisis, or a Crisis of Credit? Microcredit Lending, the Grameen Bank, and Informal Learning
}

\author{
Robert McGray (University of Alberta)
}

\begin{abstract}
Popular economic discourses have developed a lexicon which will often refer to economic downturns as a credit crisis. Kojin Karatani's recent reworking of Marx's analysis of the credit system however forces us to consider that credit itself may be the problem - a problem referred to here as the crisis of credit. This essay is a critical theoretical analysis of the way in which microcredit lending programs constrain informal learning so that people learn in a crisis of credit. After tracing the roots of microcredit to neoliberal gender reforms, I identify and critique three underlying justifications of the crisis of credit. Finally, I argue that understanding the credit/indebtedness process reveals how our proposed solution to a credit crisis contains new constraints for informal learning.

Résumé

Les discours économiques populaires font généralement référence aux récessions économiques alors qu' il s'agit de crises de crédit. La nouvelle perspective du système de crédit de Marx entrepris par Kojin Karatani nous force cependant à considérer que le problème se pose sur le crédit lui-même un problème en l'occurrence de crise de crédit. Cet article est une analyse théorique qui critique la façon dont les programmes de microcrédits entravent l'apprentissage informel des citoyens dans une crise de crédit. Après avoir retracé l'origine des microcrédits jusqu'aux réformes néolibérales de genre, trois justifications de taille ont été identifiées et critiquées. Pour conclure, j’argumenterai que le fait que comprendre le processus de crédit et d'endettement dévoile comment la solution proposée à la crise de crédit contient de nouvelles contraintes pour l'apprentissage informel.
\end{abstract}

\section{INTRODUCTION}

The financial instability of the last decade paved the way for many popular discourses that explained the economic conditions - at least in part - as a credit crisis. Because of this, it should be no surprise that microcredit lending, and more specifically Muhammad Yunus and the Grameen Bank's approach to microcredit lending, has enjoyed a flourish of popularity. Microcredit, an approach to development that grants small loans to impoverished people, has been building steam even before the West's economies were declared in a state of crisis. Aided by publicity from books by its proponents (Yunus, 2003; 2007) and even the endowment of a Nobel Peace Prize, the Grameen Bank has garnered attention by attempting to solve a credit crisis for many years now.

While we can find robust examples of research on the contemporary effects of neo-liberal financialization and the field of education (Klees, 2002; 2008 , for example), there has been little investigation in to the ways in which the activities of credit lending enable or constrain the informal lifelong learning 
processes of those involved. This begs the question of what skills and practices are required by those who are granted loans, to live their lives and participate in their communities in the structure of credit lending? Using the Grameen Bank's form of microcredit lending as an example, this essay is a theoretical investigation of the ways in which contemporary credit lending forms social structures which shape the way people learn to live their everyday lives. I argue that rather than remedying a credit crisis, we must consider that microcredit lending programs enframe informal learning processes in what Kojin Karatani (2005) points us to refer to - perhaps more aptly - as a crisis of credit. As such, contexts that support informal learning may be unable to provide pedagogical spaces where people can critically engage with the social practices of the world. Instead, acts of learning become relegated to providing marketable and commodifiable skills to satisfy the crisis conditions that credit lending can instil.

Within the context of Grameen's microcredit lending, the crisis of credit is justified, in part, by three assumptions. They are: 1) if a system works, it is justified in its operations (credit lending programs are justified because they meet their intended goals); 2) that economic revisionism holds a fundamental primacy as a type of change (that change occurs when people are incorporated into systems of global financialization); and 3) incorporation into the global market system entails equality (we are somehow unequal until we are granted credit in contemporary financial systems).

By using Donovan Plumb's (2008) concept of learning as a type of dwelling, my argument posits that acts of informal learning in microcredit contexts are circumscribed to solving the crisis of credit. Plumb's notion of learning-as-dwelling runs contrary to concepts of learning that are seen as superfluous phenomena of social life, and instead suggests that people "forever weave themselves into the fabric of their natural, social and cultural worlds" (p. 62). To be clear, it is not that microcredit stops informal learning processes, but instead that it constrains acts of learning so that people make their way in the world under the pressures of loan repayment. As such, how people learn to live their lives and assign value to their activities, are perpetually mediated by having to repay and participate in forms of the circulation of capital. By juxtaposing the commonly held belief that the remedy of the credit crisis is through more credit lending, with Karatani's assertion that credit lending itself spawns new problems - what I have referred to as a crisis of credit - I hope to draw attention to the skills people are required to learn to dwell in a global economy.

Before detailing how a crisis of credit may constrain our dwelling in the world, I first provide an overview of the concept of microcredit financing and the conceptual, ideological, and historical circumstances that spawned it. The final 
section illuminates Karatani's theory of the credit lending process and its ramifications for informal learning.

\section{MICROCREDIT AND ITS ADHERENTS}

At first glance, microcredit development seems to offer very lucrative solutions. As a project, it draws upon a coalition of concerns of the modern world and attempts to remedy complex systems of inequality. This coalition of concerns includes: the concern of the global north for the economic disparity in other parts of the world - although this concern always varies in both degree and depth; the disparity between genders in developing contexts; and, finally, an overarching concern to link social issues and a potential solution through financial markets. By leveraging these concerns, microcredit programs like The Grameen Bank's have attracted quite a bit of attention. Yunus (2007) proposes that, while there are many types of microcredit programs, including "poverty focused" and "profitmaximizing" programs (p. 68), his definition "describe(s) loans offered with no collateral to support income-generating businesses aimed at lifting the poor out of poverty" (p. 68). In addition, Yunus specifically identifies poor women with marketable skills as particularly promising loan recipients. In an earlier work, Yunus (2003) describes that a common repayment scheme for the Grameen Bank is that weekly instalments would be make on the loans with an interest rate of twenty percent. Also, the loan repayment is set to start one week after the loan was made to the recipient.

Originally, the Grameen Bank granted loans to groups of borrowers who would then invest extra funds in a group savings plan. Any person in the group could then get an interest free intra-group loan from this group savings. Yunus' claim was that this practice mirrors "the Bengali custom of mushti chal..., where a housewife puts away small amounts of rice every day to slowly build up a substantial reserve" (2003, p. 65). This practice however was disbanded after Grameen II, a series of changes to the Grameen program that occurred at the end of 2001 (Yunus, 2007). In its place, Yunus and the Grameen Bank opted to engage people in programs of "individual savings" (Yunus, 2003, p. 65).

While many development theorists and activists tout education as a crucial component of any development project, it is not immediately offered as a high priority in Yunus' work. For example, the Grameen Bank's social agenda is elaborated in what Yunus calls the "Sixteen Decisions" (2007, p. 58). Of these sixteen social development statements, only one explicitly mentions the role of education. It states, "We shall educate our children and ensure that they can earn to pay for their education" (p. 59). The Grameen Bank's formal position on education stresses the importance of competition: "Grameen believes that 
education is one of the primary components for moving oneself out of poverty. If current borrowers can educate their families and make their children better prepared to compete in the future, there will be a sustainable improvement for multiple generations" (2003, p. 236). This begs an obvious question: If someone wins this competition and sees improvement, what of those who lose? The concept of emancipation-through-bootstrapism has been a mantra for neoliberal agendas in the west for a number of years and is surely part of the reason that the Grameen Bank has endeared itself to the global north and left leaning capitalists.

As with any contemporary movement, the history of the generative mechanisms that bring to bear popular ideologies can easily be lost. The phenomenon of microcredit financing is no different. In fact, given the ideological components that comprise and justify microcredit theory, it can hardly be surprising that it has received the support that it does. So what are these theoretical underpinnings?

In the preface to Frantz Fanon's, The Wretched of the Earth, Jean-Paul Sartre (2004 [1961]), offers the now oft cited passage: "Not so long ago the Earth numbered 2 billion inhabitants, i.e., 500 million men and 1.5 billion "natives"" (Sartre, p. xliii). As a theoretical provocateur, Sartre drew attention to a fact that most know but most often forget or choose to ignore: we live in a world of very polemic generative and distributive processes. Sartre's purpose, of course, was to draw attention to the dichotomies of the world and how they articulate with the remnants of colonialism. While this led Sartre (2001) to develop his own work on the inequalities of the world, it also spurred the development of a whole field of studies on colonialism, neocolonialism, and postcolonialism (c.f. Bhabha, 2007; Spivak, 1987, 1988, 1999)

In addition to the cultural critiques of Sartre's philosophy and its theoretical descendants, global inequality also became a pressing theme in the social sciences - especially education. Many researchers viewed Paulo Freire's (1974) popular neo-Hegelian work on liberation and conscientization as particularly important. These varied colonial, neo-colonial, and post-colonial theories highlighted the vast bifurcations in the balance of power, wealth, and dignities in the world. Just as important however, was their notion that the answer may lie not with traditional power holders, but with the people who were once the victims of exploitation. Later on, Gayatri Spivak (1988) would trouble this concept with her reworking of the Gramscian term "subaltern" and prospects of voice and agency.

Indeed, as Freire (1974) alluded to, erasing the imbalance of material wealth, power, and cultural domination through "humanization ...(was a) central problem... of an inescapable concern" (p. 27). This problem however, has no easy 
solutions. One of the ramifications of having no easy solutions is that a great number of disparate strategies have begun to evolve. These strategies often reflect the various modi operandi of socio-political ideology.

One of the responses to the dichotomous nature of what David Harvey (2006) refers to as spaces of "uneven geographical development" (p. 71) has been the increasing calls for the alteration of dominant economic systems to alleviate pressure on the developing world. This trend can be traced to two factors. The first is the subtle (and slow) recognition that the world possesses vast inequalities that have led to Sartre and Freire's concerns of dehumanization; the second factor is the predominance of revisionist versions of economics that have begun to dominate global consciousness. This can be seen through neoliberalism's call for the economization of social and cultural life. By understanding the trend to merge these two factors, we can begin to realize how microcredit lending schemes have begun to develop a prominence in development ideology. This ideology finds its emergence where economistic strategies attach themselves to the general consideration of the plight of postcolonial and financially disenfranchised subjects.

\section{THE GRAMEEN BANK AND GENDER REFORMS}

Grameen's microcredit program is now one of many varied strategies for alleviating poverty. It is likely that it would not have achieved notoriety were it not associated with several important political-economic strategies. Most notable amongst these is the focus on women as the locus of economic development. As Gayatri Spivak (1999) states, the targeting of women means that "in the new international economic order... it is the labor of the patriarchally defined subaltern woman that has been most effectively socialized" (p. 68). Spivak further describes the contemporary ideologies that, when read together, I argue have led to the development of programs like microcredit. These ideologies combine "postfordist homeworking (classical coding of the spectrality of reason as empiricist individualism, complicated by gender ideology)" (p. 68), and the "global project... (of) planetary financialization" (p. 70, parentheses added).

Commenting on the contemporary shift in focus in development to women's contexts, Jennifer Hales (2007) notes that in microcredit contexts, such as those advocated by the World Bank,

Women are seen as a means to other (economic) ends. The World Bank's micro-credit programmes provide another example of how women are targeted in development for economic reasons. Micro-credit programmes, while potentially giving women greater bargaining power 
in the household, for example, ultimately can be seen as a way of incorporating women into the market to improve the economy. (p. 150) Hales raises a question that is difficult to overlook or resolve: How can we avoid providing (or find the will to provide) small windows of agency to people that justify structural inequalities? Hales notes that large financial institutions like the World Bank give the illusion that they are, "committed to social change and improving the lives of poor women. However,... an analysis of the World Bank's gender policies reveals a neoliberal economic agenda that takes precedence over social goals of equality and justice" (p. 154).

Jennifer Hales also draws on the work of Katharine Rankin (2001) to understand the connection between gender reforms and microcredit projects. Rankin's study of specific microcredit projects in Nepal offers a detailed account of the ways microcredit organizations have been aided by the devolution of the state's role in alleviating poverty. To be clear, Rankin's thesis is not that the state disappears in its efforts to alleviate poverty, rather, it changes its focus to adopt a market driven approach. She notes that, "The role of the state under these circumstances is reduced to deregulating or liberalizing distinct national economics to facilitate the flow of capital and the competitiveness of markets" (p. 21). As such, the state's facilitation of market driven approaches to poverty alleviation has led to the increase of corporate interests. Rankin herself points to "Citicorp, Chase Manhattan, and American Express" (p. 19) as pledged sponsors of microcredit programs around the world.

Rankin, like Jennifer Hales, does admit the possibility that women in microcredit lending programs can sometimes find avenues of action that were not open to them before. She does, however, provide the caveat that "microcredit must also be recognized as a state strategy that constitutes social citizenship and women's needs in a manner consistent with a neo-liberal agenda" (p. 20). She continues to note that "as such it illustrates clear connections between state power and gender oppression" (p. 20). These forms of oppression leverage the needs of impoverished people to deepen their embeddedness in forms of global capital. Further to this point, Rankin also discovered that the rationality of microcredit utilized the aura of community to form specific relationships between the female recipients and the credit lending process. Because early forms of microcredit often encouraged groups of women to organize in solidarity groups (also called borrower groups), many proponents of microcredit heralded this as advancing rural women's agency. Rankin argues that, instead of being in a community that served the interests of rural women in social activities, under the influence of microcredit, their newfound communities were tied together by the objectives of global financialization projects. As she explains, "Within the 
framework of neoliberal rationality, then, solidarity groups assume as their primary objective the financial health of microcredit programs, rather that the welfare (indeed solidarity) of the rural population" (p. 29). Rankin urges us to question, "what kinds of subjectivity does microcredit aim to cultivate among the rural poor... particularly women, by means of new modes of self-regulation?" (p.

22)

\section{THE JUSTIFICATION OF CREDIT}

For many, including proponents of the Grameen Bank, current forms of credit lending are simply not a problem. This will continue to be an ideological divide of the modern world. On one side, there are those who would find merit in a financialized version of Fukuyama's (1992) thesis and assume that market economies have formulated an epochal historical climax. On the other side, there are those who would reject the primacy of markets for the development of social and cultural lives. For the former category, there are three primary justifications that are assumed to be true. These justifications underpin the neo-liberal ideology and enable an unexamined ethic to drive such projects, often under the assumption that this unexamined ethic is naturalized and inherent to humans and society. They are:

1) If a system works, it is justified in its operations (credit lending programs are justified because they meet their intended goals). Proponents of microcredit use this assumption to identify merit because intended outcomes have been met. What is not addressed is whether or not intended goals, if met, are necessarily ethical. Yunus' $(2003,2007)$ work responds to his critics by arguing that microcredit is a viable (even a desirable) form of development because it works. Indeed Yunus' claims are that the intended goals of the project have been in accordance with what has actualized in the world. This pragmatic logic is appealing. This logic, however, does not necessarily carry ethical justification about those goals and results. We must consider that while there are many acts that meet their intended results, neither the act nor the results, are ones that we would want to constitute our world. This type of critique of microcredit is leveraged by Lamia Karim (2008). In her recent work on the effects of microcredit and the Grameen Bank's work with rural women in Bangladesh, Karim challenges the functionalist discourse that revolves around microcredit. Instead, she examines how the intended goals, and subsequent results of microcredit and NGOs relate to the culture of rural women. Karim found that microcredit has succeeded in the Bangladesh context because "rural women's honor and shame are instrumentally appropriated by NGOs in the welfare of their capitalist interests" (p. 6). More specifically, Karim's analysis revealed that 
appropriation was a result of microcredit being placed within "the political economy of shame" (p. 6). The concept of the "economy of shame" is an intriguing point. Karim explains that this term refers to the ways that the Grameen Bank has used, often in celebratory ways, the concept of honour and shame to ensure that their loan recovery system works efficiently. The systems of shame for the rural poor in Bangladesh, is as Karim describes, not a new concept.

Shaming takes many forms in Bangladeshi rural society, from rude language to regulation of women's sexuality to disciplining of poor people through accusations of sexual infidelities resulting from public floggings, pouring pitch over bodies, tonsuring women's hair, hanging a garland of shoes around one's neck, to isolating one's family in the village, to publicly spitting on the person every time s/he walks by, to making adults hold their ears as a sign of their guilt in a public forum, to breaking apart a person's house to recover money, and so on. (p. 10)

As such, Karim's research on microcredit has shifted the attention from the function of microcredit, to issues of ethics. This means that microcredit cannot be seen simply as a neo-liberal solution to poverty, but at least in part, as a system of global financialization where "the honor and shame codes act as the collateral of these loans" (p. 10). Karim's work allows us to conceptualize the organization of microcredit in a very important way. While Yunus has spent a great amount of effort to defend Grameen's project as one that meets its intended goals in relation to loan recovery, Karim points out that what Yunus has championed the most, may in fact be problematic. Loan recovery is not necessarily a sign that a development project is working in accordance with all ethical frameworks.

2) The second justification of credit ideology is that economic revisionism holds a fundamental primacy as a type of change (that change occurs when people are incorporated into systems of global finance). Practitioners of education hold a certain priority for the term "change" in the lexicon of learning. In fact, whole schools of learning theory have been built around the notion that learning provides substantive and culturally valuable avenues for change (I refer here to the field of transformational learning such as elucidated by Jack Mezirow, 1991). Because of education's long history with the concept, the field is often drawn to discourses that claim social change.

The Grameen Bank provides us with an interesting, but fairly widespread, contemporary example of what the term change in a socio-economic sense may be perceived as. Examples are common in Yunus' literature that speak to the prospect of change; almost all refer to specific economistic strategies where change takes place by including people who have been previously alienated or exploited into systems of global credit and indebtedness. As Wendell 
Berry (1994) asserts, this rationality often assimilates people who have been treated unfairly, into a system of capitalism which can treat everything unfairly.

Elsewhere (McGray, 2008), I have pointed out that Margaret Archer (1995) has elucidated a differentiation between morphogenetic and morphostatic change to illustrate the problematic of the word change. Archer, avoiding functionalist sociological trends, posits that it is true that the world is always changing. As such, most people can leverage the claim that they are changing the world. With the distinction between morphogenetic change (when change generates new conditions of the world), and morphostatic change (when change reproduces or justifies existing conditions), Archer establishes criteria for the assessment of the affects of the term change. By differentiating between these terms, we realise that when we change things, we can also work to maintain preexisting systems. In short, there can be distinctions between change which reproduces conditions of the world, change which ameliorates inequalities, and change that falls between these two positions.

3) Finally, the third justification of microcredit ideology is that inclusion into the global market system entails equality (that those who are granted credit in contemporary financial systems are perceived to be equal). Yunus has even tried to solidify this claim by advocating credit as a human right. While this is a compelling argument, questions have been raised pertaining to the applicability of credit lending as constituting an inalienable or fundamental right. Marguerite Robinson's (2001) World Bank publication points out, contra to Yunus' rights based argument that, "food is a universal need; credit is not" (p. 26).

To develop an argument decrying anything as a human right is actually a common strategy. As Habermas (2001) notes, rights based discourses are one of the methods "from which an enacted, changeable law is supposed to be legitimated as a means to secure both the private and civic autonomy of the individual" (p. 116). In addition, he goes on to argue that the rights based arguments stem "from the attempt to answer specific challenges posed by a social modernity that has in the meantime covered the globe" (p. 121). While the discourse of credit-as-a-human-right serves to convey the ideology as just, it overlooks one major point. Instead of intellectual credit where a homage to labour is paid, the financialized version in microcredit has two necessarily connected acts. While the first is the act of the credit (by the creditor), the second is that someone (the debtor) becomes indebted. In the microcredit program, these acts exist simultaneously. If equality is enabled through these loans, then one must also argue that the second necessary step of indebtedness is also a human right. 


\section{INFORMAL EDUCATION}

In the first few sections of this essay, I have attempted to describe and trouble the processes which have generated microcredit programs. These processes include the financialization of home life, revisionist economics of capitalism, and the neoliberal belief that the economy is a harbinger of social transformation. While I have detailed the rapid increase in popularity and attention that microcredit lending programs have made, it still must be asked why microcredit should be a consideration for those of us interested in education? Even more specifically, it must be asked why the implications of microcredit programs should be considered for an understanding of the concept of informal learning (and vice versa)?

In employing the term informal learning - a somewhat elusive phrase - I refer to the ways in which people learn their way into physical, social, and cultural practices of everyday life. While the field of informal learning has not been the most heavily trodden academic path over the years, there are still some who would attempt to convey the importance of the concept. One such person, Donovan Plumb (2008), describes our acts of learning analogous to the act of dwelling. He notes,

Through dwelling, we bring the emergent, developing capacities of our bodies and the unfolding powers, regularities and unpredictability of nature and society into productive, creative relation. As a consequence of our practical engagement in the world, both we and the world transform. The world of natural and cultural artefacts is diverted by our energies into new patterns that become the environment for subsequent engagements by us and other beings. At the same time, our own bodies are diverted by our practices to develop new patterns and powers that become the basis for future engagements with the world. (Plumb, 2008, p. 74)

To elucidate a deepened understanding of the nature of informal learning, Plumb draws upon concepts from Martin Heidegger and anthropologist Tim Ingold. The concept of dwelling challenges pedagogical notions of learning that depict humans as agents apart, separate, or above the material conditions in which we live. As such, Plumb's dwelling concept emphasizes that "capacities for social agency arise from, extend, but never abandon our more pervasive human power for learning as dwelling" (p. 63). As Plumb merges the older Heideggerian concept together with a Critical Realist perspective, he alerts the study of informal learning to two important considerations. The first is that our interaction with the material world is not simply a vulgar realist claim of an independent material world, but rather, he emphasises a co-evolutionary 
interaction that forms complexity through its development. The second is that Plumb's lens on learning provides the tools for an investigation of the ways in which the subjectivities of those involved in microcredit are constituted, and, in addition, it focuses our attention on the material contexts that subjects find themselves habituating.

With Plumb's conception and formulation of our everyday informal learning practices as dwelling, we can ask ourselves how development projects like microcredit lending are inextricably woven into forming the learning processes of our everyday lives. Rather than viewing the activities that people learn in development programs as specific and compartmentalized tasks, Plumb elaborates the importance of learning as something that operates as a system of activities (see contemporary activity theory literature: Roth \& Lee, 2007; Yamagata-Lynch, 2007) that profoundly alters the ways in which we dwell and make our way through the "natural, social and cultural worlds" (p. 62). The power that informal learning evokes is such that specific activities like learning to participate in a cycle of credit lending/borrowing, can substantively alter the way in which we dwell in our environment. It is important to note though, that using Plumb's conception of lifelong learning does not simply provide us another lens with which we can view the effects of microcredit lending. Due to the inherent role in everyday lives that learning plays, the focus on how people learn in community contexts is, in fact, a necessary consideration that must be taken to understand critically the social and natural environments.

Learning, when viewed through Plumb's framework, should pique our interest into the social relationships that are formed, in part, through microcredit relationships. While we should grant attention to the ramifications of the economization of formalized school systems - here I refer to Yunus' theories of being able to pay for schooling - it also becomes crucial to understand how people become socialized within various rules and systems of credit lending.

\section{CREDIT CRISIS VS. A CRISIS OF CREDIT}

How then can we understand how our learning/dwelling is enabled or constrained by microcredit schemes? Recently, one of the more potent insights into the nature of exchange has come from Japanese philosopher, Kojin Karatani, in his book Transcritique, (2005). In light of the faith instilled in credit lending, Karatani would have us question whether the perceived solution to financial freedom (in microcredit's case this is the act of credit lending), may in fact open up new problems. Karatani and Marx both argue that the root of a credit crisis is explained in the economic commodity form represented in Marx's original 
taxonomy as $\mathrm{M}-\mathrm{C}-\mathrm{M}^{1}$. This equation represents the exchange between money (M) and commodities (C). Karatani states,

As Marx pointed out, capital is engendered at the point where selling (C$\mathrm{M})$ and buying (M-C) are separated spatially and temporally. The separation not only fosters surplus value, but also eventually causes a credit crisis. This separation cannot be collapsed, and it is wrong to presume that direct exchange is ever possible. (p. 222)

Previous to this, he notes,

Crises nevertheless do not dissolve capitalism; rather this is a capitalistic solution to the problems inherent in capitalism, and part of the whole process of the prosperity cycle (prosperity-crisis-depression-prosperity). Crisis and the depression that follows are merely parts of the violent (or liberalistic) reformation of capitalist production. The same periodical crises of Marx's age are no longer existent, precisely like the victims of hysteria caused by sexual repression that Freud encountered. Yet, so long as capitalism is a world constituted by the credit system, crises will continue to dog it. (pp. 220-221)

It is worth noting here that Karatani takes a slightly different stance on a credit crisis than Marx did. While Marx, like Karatani, states that credit "accelerates the material development of the productive forces and the establishment of the world-market" (p. 441), Marx also held that "credit accelerates the violent eruptions of this contradiction-crises - and thereby the elements of disintegration of the old mode of production." (p. 441)

Until this point, Karatani's mention of the credit crisis is the popular and contemporary usage of the term. That is to say, an analytic description of capitalism that has led people to believe that credit is what is required to solve the problems inherent in capitalism. He would counter that the root of the problem comes from the very formulation of society that is organized through the act of credit lending. This is what I have referred to as the crisis of credit. The juxtaposition of the two phrases - credit crisis, and a crisis of credit - are possible due to Karatani's definition of the term crisis. He notes that "Crisis is a chronic disease inherent in the capitalist economy, yet also a solution to its internal defects. In other words, capitalism makes temporary repairs to its innate problem by crises" (p. 157). In this way, Karatani likens the credit crisis to the psychoanalytical concept of hysteria. While the hysteric patient ultimately suffers from the condition, the hysteria also solves another ill (this ill, being one of panic, stress, trauma, etc.). With this analogy, Karatani offers a segue back to the consideration of everyday informal learning. As he states, key to the Freudian analysis of the hysteric patient, was the understanding of the unconsciousness 
that spawned the hysteria. Likewise, "for Marx, crisis was no longer the terminator of capitalist economy. It became important only because it would reveal the truth of the capitalist economy that is invisible in the everyday economy" (p. 157).

How then, does one come to understand this so called truth? The answer according to Karatani, it to investigate Marx's basic expression of the movement of capital. That is, Money-Commodity-Money' (M-C-M'). This expression becomes key as he notes that "Marx began his scrutiny from the process of circulation because the kernel of capital exists in the formulation of the archicapital M-C-M', and because capitalist production cannot exist if not for the world market engendered by this formulation." (p. 223). According to Karatani, credit becomes institutionalized to capitalism through a "transcendental illusion" (p. 217), that is, a faith in the markets by the creditor that commodities can be sold in the future, hence potentially providing profit. In this way, credit allows economics to pre-empt the final selling of commodities (the movement from CM') to start the process again. Instead, Karatani notes that "the essence of credit lies in its avoidance of the critical moment inherent in the selling position- the postponement of the present perplexity to the future" (p. 219). As a result, "under the credit system, the self-reproduction of capital occurs not because of its desire for accumulation; it becomes compulsive because of its desperate need to infinitely postpone the final settlement" (p. 219). This description explains the initial credit crisis.

I would argue though, that through reading Karatani's analysis against microcredit contexts we not only understand how this constant compulsion for postponement fosters a credit crisis, but just as importantly, the movement M-CM' explains the act of Grameen's microcredit lending and is thus also read as a crisis of credit. In the granting of microcredit's financialized loan, the emphasis, and Yunus' own justification of the success of the loan, is focused on the repayment. Microcredit loans initially are granted with the faith that money will be repaid, and interest will be accrued from it. This mirrors the previously described movement of the beginning of a credit crisis. But I would also argue that it is the beginning of a crisis of credit. The faith that the creditor has that money will be made cannot be ignored as a constraint on the debtor. If, on a systemic level, Karatani's description of a credit crisis requires that capital postpones final settlements, a crisis of credit on a subjective level of the debtor of the loan stresses repayments. In both cases though, the movement of M-C-M' acts as Karatani previously described it as "compulsive" (p. 219). In the case of microcredit, the pressure to repay the loan de-emphasises the commodity and the labour required to produce it. As such, and similar to many movements of capital, 
the commodity is only a place holder in this equation. What products are produced? How are they produced? What skills and knowledge are required by the debtors of the loans to produce commodities to sell and fulfill the debt owed? What ethical insulation is provided to debtors to enable the production of goods that is environmental sustainable and socially responsible? For education and informal acts of learning, these questions are paramount. In fact, I would argue that one of the defining features of a crisis of credit, is the transference of emphasis from the skills learned to engage in fulfilling and valuable labour, to the emphasis on garnering money to pay back the loan. As I have pointed out earlier, Yunus' commitments in education in the Grameen Bank's 'Sixteen Decisions" only highlight that students should be able to pay for education. Again, the crisis of credit abandons discussion of what people should learn and replaces it with a faith that market solutions will solve society's ills.

Karatani ends his work with a hopeful proposition. He proposes that through the theorization of credit and subsequent relationships between creditors and debtors, we can find alternate economic practices to solve existing problems and crises. One such avenue, he notes, is the development of Local Exchange Trading Systems (LETS). In LETS, communities exchange services and goods for credits, or other goods and services. As such, the problem is not with economies or currencies (the credits act in a similar manner to money) but with exploitative systems. Karatani asserts that the LETS systems proposes a different ethic for development and economy, as the system does not allow another to accrue excessive interest, or pressure labour into forms which only serve to satisfy loan repayment. Also, the LETS credit system provides mechanisms which attempt to circumvent hoarding and the fetishization of money. While it is beyond the scope of this paper to offer a discussion of Karatani's theory on LETS, it is worthwhile to acknowledge that the theorization of many of these issues can work to avoid some of the concrete ethical predicaments that people face daily.

As debtors in microcredit scenarios work to repay loans, the crisis of credit only emphasises that money must be repaid. The habits, skills, social relationships, and how we dwell in the world is learned in a context of compulsive repayment. Because little emphasis is paid by the Grameen Bank to understand what, and how, people learn to produce repayment, the drive for repayment constrains what people learn, and how they dwell. Far from being natural or inherent relationships, these constellations of political economy are formally and informally learned relationships. To merge this proposition with the concept of our learning as analogous to how we dwell in the world, we return to my thesis: that instead of a credit crisis, we have failed to consider how the drive 
for credit has instilled a crisis of credit. It is this crisis of credit, which seems to be both pervasive, and at the same time, elusive to identification, that offers complex constraints on the ways in which we learn and dwell in the world.

\section{References:}

Archer, M. (1995). Realist social theory: the morphogenetic approach. Cambridge: Cambridge University Press.

Berry, W. (1994). Sex, economy, freedom, and community. Toronto: Random House Canada.

Bhabha, H. (2007). The location of culture. New York: Routledge.

Freire, P. (1974). Pedagogy of the oppressed. New York: The Seabury Press.

Fukuyama, F. (1992). The end of history and the last man. New York: Perennial.

Habermas, J. (2001). The postnational constellation: political essays. Cambridge: The MIT Press.

Hales, J. (2007). Rhetoric and reality: World Bank and CIDA gender policies. Convergence. Vol. XL, no. 1-2.

Harvey, D. (2006). Spaces of global capitalism: toward a theory of uneven geographical development. London: Verso Press.

Karatani, K. (2005). Transcritique: On Kant and Marx. Cambridge: The MIT Press.

Karim, L. (2008). Demystifying micro-credit: the Grameen Bank, NGO's, and neoliberalism in Bangladesh. Cultural Dynamics. 20(1), p. 5-29.

Klees, S. (2002). World Bank education policy: new rhetoric, old ideology. International Journal of Educational Development. vol. 22 pp. 451-74.

Klees, S. (2008). A quarter century of neoliberal thinking in education: misleading analyses and failed policies. Globalisation, Societies and Education. Vol. 6, No. 4. pp. 311-348.

Marx, K. (1974 [1894]). Capital, Vol. 3.: the process of capitalist production as a whole. New York: International Publishers.

McGray, R. (2008). Adult Education, International Development, and Theories of Social Change: Between Complicity and Transformation. In, Groen, J. \& Guo, S. (Eds.) Canadian Association for the Study of Adult Education (CASAE) Annual Conference. Vancouver, British Columbia. Pp. 246-252.

Mezirow, J. (1991). Transformative dimensions of adult learning. San Francisco: Jossey-Bass.

Plumb, D. (2008). Learning as dwelling. Studies in the Education of Adults. Vol. 40, No. 1, pp. 62-79.

Rankin, K.N. (2001). Governing development: neoliberalism, microcredit, and rational economic woman. Economy and Society. Vol. 30, No. 1, Feburary, pp. 18-37.

Robinson, M. (2001). The microfinance revolution: sustainable finance for the poor. Washington: The World Bank.

Roth, W.M., \& Lee, Y.J. (2007). "Vygotsky’s neglected legacy": cultural-historical activity theory. Review of Educational Research. 77 (2), pp. 186-232.

Sartre, J.P. (2004 [1961]). Preface. In, Fanon, F. The Wretched of the Earth. New York: Grove Press. Pp. Xliii1xii.

Sartre, J.P. (2001). Colonialism and neocolonialism. New York: Routledge.

Spivak, G. (1987). In other worlds: essays in cultural politics. New York: Methuen.

Spivak, G. (1988). Can the Subaltern speak? Marxism and the Interpretation of Culture. Nelson, C. \& Grossberg, L. (Eds.), Urbana: University of Illinois Press. Pp. 271-313.

Spivak, G. (1999). A critique of postcolonial reason: toward a history of the vanishing present. Cambridge: Harvard University Press.

Yamagata-Lynch, L. (2007). Confronting analytical dilemmas for understanding complex human interactions in design-based research from a cultural - historical activity theory (CHAT) framework. Journal of the Learning Sciences. 16 (4), pp. 451-484.

Yunus, M. (2003). Banker to the poor: micro-lending and the battle against world poverty. New York: Public Affairs.

Yunus, M. (2007). Creating a world without poverty: social business and the future of capitalism. New York: Public Affairs.

Robert McGray (mcgray@ualberta.ca) is a PhD candidate whose research examines critical theory, citizenship education, and lifelong learning. He also teaches part-time in the Cultural Studies Department at Mount Saint Vincent University. 